\title{
Szegedy-Maszák Zoltán
}

\section{Az anyagon túl. Interjú Lívia Nolasco-Rózsással}

\section{Szerzô}

\section{Lívia Nolasco}

Nolasco-Rózsás Lívia kurátor, múvészettörténész. 2006 óta világszerte rendezett kiállításokat kortárs és médiamúvészeti intézményekben, többek között a ZKM | Center for Art and Media Karlsruhe, a shanghaji Chronus Art Center, a koreai Nam June Paik Art Center, a tallini és a budapesti Múcsarnok kiállítótereiben. Az általa kurált tematikus kiállítások olyan kérdéseket vetnek fel, mint az információs technológia globális hatása, a számítógépes kódok genealógiája és társadalmi vetülete, az elektronikus megfigyelés és demokrácia kapcsolata, a tér fogalmának változása a virtuális és generatív terek elterjedésével, vagy a szinesztetikus érzékelés.

2019-ben a lipcsei Képzőmunvészeti Akadémián indított kurátori kutatást a „virtuális állapotról” és annak következményeirôl. Párhuzamosan a ZKM | Karlsruhe BEYOND MATTER címú nemzetközi együttmúködési projektjének kezdeményezője és vezetője.

\section{Szegedy-Maszák Zoltán}

Képzőmúvész, egyetemi tanár; 1969-ben született Budapesten. Diplomáit a Képzômúvészeti Egyetem Festô-, majd Intermédia Szakán szerezte, ahol 1992 óta oktatóként is dolgozik, jelenleg a Doktori Iskola vezetôje. A Széchenyi Irodalmi és Múvészeti Akadémia és a Nyílt Struktúrák Múvészeti Egyesület tagja. Múvészete ahhoz a tendenciához kapcsolódik, amelyet az új képfajtákkal (fotó, film, videó, digitális technológia) kísérletezô, a kutatást, a tudományt és a múvészetet egységben láttató képzômunvészek képviselnek Magyarországon. Múveiben a technikai médiumok széles spektrumát alkalmazza az analóg fotokémiai eljárásoktól a digitális nyomatokon át a számítógépes interaktív installációkig. Nemzetközi elismertségét a 90-es évektól készített virtuális, illetve kevert-/kiterjesztettvalóság-alapú installációi hozták meg, melyek speciális interfészek, illetve a digitális technika kreatív használatán keresztül teszik megtapasztalhatóvá a számítógéppel elóállítható illuzionisztikus környezeteket.

https://doi.org/10.31176/apertura.2021.16.2.4 


\section{Szegedy-Maszák Zoltán}

\section{Az anyagon túl. Interjú Lívia Nolasco-Rózsással}

Szegedy-Maszák Zoltán: Nagyjából a romantikával született, majd egészen a huszadik század végéig makacsul kitartott a köztudatban egy olyan kép a képzőmúvészetrôl, annak befogadásáról, amely elsődlegesen az eredeti mútárggyal való találkozáson alapult. A múalkotás tárgyszerúségének, eredetiségének varázsa az, amiért galériákba, múzeumokba látogatnak az érdeklôdôk; a múgyújtô szenvedélye - vagy befektetési szándéka - is az eredeti tárgyak birtoklására irányul. A Beyond Matter projekt gyökeresen másképpen értelmezi a múvészetet, történeti utalásaiban is olyan kiállítások megidézésével foglalkozik, melyek a huszadik század végén és a kétezres évek elején megkérdôjelezték az eredeti és tökéletes mútárgy kizárólagos kultuszát. Kezdésként el tudnád mondani, hogy általában mi is ez a projekt?

Lívia Nolasco-Rózsás: A Beyond Matter egy nagyobb lélegzetû, négyéves, gyakorlati kutatáson alapuló program, amivel már 2019 vége óta foglalkozunk a ZKM-ben, ${ }^{[1]}$ számos partner múzeumok és egyetemek - bevonásával. Közéjük tartozik a párizsi Centre Pompidou, a finn Aalto Egyetem, a budapesti Ludwig Múzeum, a Tallini Múcsarnok (Tallinna Kunstihoone), a Tirana Art Lab és az EPFL Art Lab Lausanne is. Térben és idôben is meglehetôsen széles tehát a perspektívánk, de talán mindenek elôtt érdemes utalni a kérdésben megbúvó hivatkozásra: Walter Benjamin 1936-os, nagy hatású, A múalkotás a technikai reprukálhatóság korában címú szövegére, [2] mely a képzômúvészet, illetve általában az eredeti múvek befogadásával kapcsolatban kiindulópontként szolgál megjelenése óta, ráadásul bevezeti az „aura” fogalmát a múvek eredetiségével kapcsolatban. A mi kiindulópontunk azonban nem az egyes múvek, hanem a felidézett kiállítások aurájával kapcsolatos. Konkrétan arra keresem a választ, hogy a múvek kapcsolatai, együttes jelentésük hogyan jön létre egy kiállítás „színpadra állításakor”, hogyan befolyásolja azt a kiállításépítészet, a szcenográfia - és mindez hogyan adható át vagy idézhetô meg a digitális rekonstrukció keretei között.

A téma nem tûnt különösebben központi jelentôségúnek 2020 elôtt, amikor a múzeumok, galériák a pandémia következtében bezárni kényszerültek. Kezdetben úgy gondoltunk erre, mint a távoli jövôben aktuálissá váló kérdésfeltevésre, amely megelôzi saját korát. Hirtelen azonban érdekessé vált azoknak a vizuális múvészeti tartalmaknak az átültetése a digitális térbe, amelyek addig a megszokott fizikai valóságukban álltak a kiállítás látogatóinak a rendelkezésére.

A pandémia elôtt csak sporadikusan fordult elô, hogy múzeumok a saját kiállításaikat online tegyék bejárhatóvá, és kizárólag online eseményeket szervezzenek. A Beyond Matter projekt alaptézise viszont éppen az, hogy egy-egy kiállítás a digitális térbe is kiterjeszthetô. A múzeumok eddig is nagyon sokféle formátumot használtak arra, hogy múalkotásokat állítsanak ki, hogy 
azokat kontextualizálják és megismertessék a látogatókkal, legyen az egy kiállítás vagy valamiféle performatív esemény. Sok esetben a múvek közötti tér, a múvek egymáshoz való viszonya és a kiállítás vagy esemény helyszíne meghatározó fontosságú a kiállítás értelmezésében. Ebból is adódik, hogy a Beyond Matter esetében a digitális tér szerepe központi jelentôségú. Amikor 2018ban elkezdtünk a projekten dolgozni, még egyáltalán nem volt világos, hogy milyen lehetôségeket rejt a hálózaton keresztül elérhetô digitális tér. Eleinte a mainál jóval óvatosabb elképzeléseink voltak arról, hogy egy megidézett kiállítás aurája mennyire ültethetô át a számítógép által generált valóságba.

A projekt több oldalról közelít a kérdéshez; talán az olvasók is találkoztak már a Spatial Affairs / Térügyek címú kiállítással, amely idén május-júniusban volt látható a budapesti Ludwig Múzeumban - illetve online formában továbbra is látogatható a Beyond Matter weboldalán ( https://beyondmatter.eu), ahol egy külön ennek szentelt oldalon a különbözố online kiállításainkat tesszük közzé (https://beyondmatter.eu/projects). Itt többek között a Térügyek fotogrammetrikus másolata vagy digitális ikertestvére is elérhetô, a kiállítás virtuális kiterjesztésével, a Spatial Affairs. Worlding - A tér világlása címú online környezettel együtt. Ha a címben valaki Heideggeráthallásokat vél felfedezni, akkor nem téved.

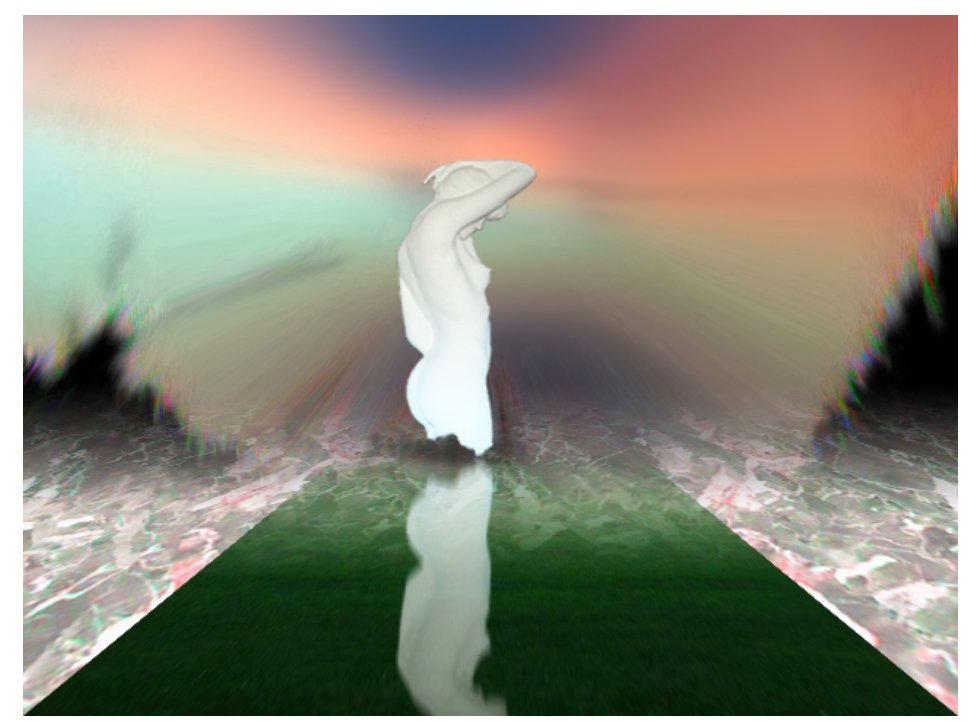

Petra Cortright: The infinite sculpture garden without the boundaries torn and ripped into the vacuum of emptiness (2010)

Akár úgy is fogalmazhatnánk, hogy a Spatial Affairs voltaképpen alapkutatás a Beyond Matter tézisének igazolására, melyben a tudomány és a múvészetek reakcióját vizsgáltuk a tér fogalmára az információs technológia fejlődô térképzési lehetôségeinek tükrében. A Spatial Affairs kiállításon belül megpróbáljuk ezt az elejétôl végigkövetni, tehát mondjuk Tamkó Sirató Károly harmincas években írt Dimenzionista manifesztumától [3] kezdve egészen Georg Nees elsô számítógépes nyomatain keresztül olyan virtuálisvalóság-installációkig, amelyek teljes egészében kihasználják a számítógép által generált tér jelenkori lehetôségeit. A kiállításhoz kapcsolódó digitális, csak online hozzáférhetô rész, A tér világlása pedig a White Cube-tól, ${ }^{[4]}$ vagyis a „fehér kockától” teljesen elrugaszkodott online tér. A fehér kocka eleve egy ambivalens fogalom, ami a 20. század második 
felében csupán néhány évtizedig jellemezte a képzőmunvészet kiállításának feltételeit, de például a Ludwig Múzeum kiállítótereit máig meghatározza, és ennek megfelelôen letisztult és visszafogott hátteret próbál biztosítani a mútárgyaknak. A fehér kockát megelózően azért egészen máshogy néztek ki a kiállítóterek. Ezt tudjuk például az impresszionisták kiállításairól fennmaradt dokumentumokból, vagy például abból, hogy a Velencei Biennále Giardinijához eredetileg tartozott egy pálmaház is, amely a kiállításokon használt növényeknek nyújtott a két biennále között menedéket, abban az idôszakban, amikor még dekoratív elemek használatával igyekeztek azt a hideg atmoszférát meggátolni, amelyet kizárólag mútárgyak teljesen üres térben való kiállítása tud okozni. A késôbbi White Cube-nak vagy fehér kockának pontosan ez volt a célja, a múvek kizárólagos szerepeltetése és hangsúlyozása - ez a kiállítási praxis, amelyet többek között Brian O’Doherty írt le, és elitista jelenségként kritizált már a hetvenes években az Artforum hasábjain, máig nagyon sok esetben meghatározza a kortárs kiállítótereket.

Ezt a kanyart azért tettem, mert a digitális térképzés reakciója erre az ambivalens tradícióra $A$ tér világlásának tárgya, ahol teljességgel elhagytuk a falakat, az épület- és a múzeumszerúséget a kiállítótérbôl. Inkább organikus élőhelyként vagy ökoszisztémaként lehetne leírni azt, ami a digitális térben „kinôtt”. Az itt található múvek mind szoftveralapúak és mind online elérhetôek, mi csak összegyújtöttük ôket ebbe a világló kis térbe, ahol avatárokkal vannak jelen, folyamatosan mozognak, a látogatónak pedig az a feladata, hogy „elkapja” a múveket ahhoz, hogy meg tudja nézni ôket. Ez teljesen más befogadói attitúdöt implikál, mint egy fehér kocka, ahol a kurátor dönt arról, hogy hogyan vezeti végig a kiállítótéren látogatót, hogy melyik múvet nézi meg elôször, és mikor mivel találkozik.

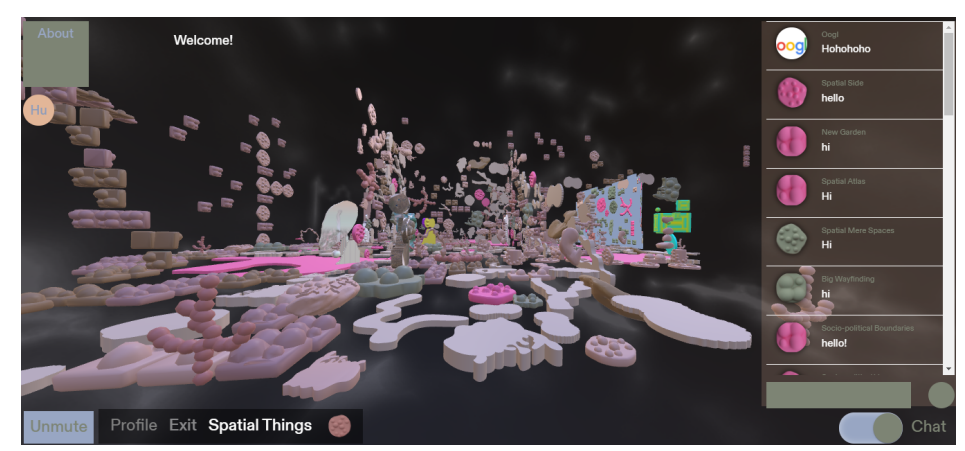

A Térügyek címú kiállitás kezdöoldala 
A digitális térképzés kérdésköréhez tartozik két múltbéli kiállítás, az 1985-ben a Pompidou központban megrendezett Les Immatériaux és a 2002-ben a ZKM-ben bemutatott Iconoclash digitális megidézése is. Nem beszélnék rekonstrukcióról, inkább kiállításmodellekrôl, mert nem digitális másolatokat készítünk ezekrôl a kiállításokról, hanem megpróbáljuk ôket emulálni, felidézni és digitális platformokon, fizikai kiállítóterekben és online bemutatni. A Les Immatériaux Jean-François Lyotard és Thierry Chaput rendezésében volt 1985-ben látható, míg az Iconoclashegy egész kurátori csapat munkájának eredményeként, Bruno Latour és Peter Weibel vezetésealatt, a képrombolás kérdéskörét járta körül a vallás, a politika, a történelem és a tudományokterén.

E két kiállítás modelljét online, böngészôben jelenítjük meg - ezen keresztül kíséreljük meg a kiállítások szcenográfiában is megnyilvánuló lényegét megragadni, és digitális térbe konvertálni. Fontos megemlíteni, hogy az online hozzáférés mellett szeretnénk ezeket a modelleket múzeumlátogatók számára is hozzáférhetôvé tenni egy jelenleg Immaterial Displaynek nevezett kijelző segítségével, amely semmiképpen sem egy anyagtalan hardvereszközt jelent megjegyzem, a hardver mellett természetesen a szoftver sem nevezhetố anyagtalannak, még akkor sem, ha ez látszólagos és egyben feszültségekkel teli ellentmondás.

Mindkét kiállításmodell esetében abból indultunk ki, hogy nem feltétlenül a teret vagy a szcenográfiát szeretnénk reprodukálni, hanem megpróbáltunk a kurátori koncepcióhoz húek maradni, és ahhoz alkalmazkodva újat létrehozni. Az Iconoclash kiállítás esetében több interjú után a kurátorokkal és az építésszel arra jutottunk, hogy a digitális teret a szcenográfia folyamatosan újraképzésére használnánk, ami a ZKM kiállítóterében statikus kellett hogy legyen. A digitális térben ezzel szemben lehetséges olyan folyamatos mozgás, ami akár ikonoklaszta gesztusként is felfogható. Ennek az az eredménye, hogy nem egyetlen szcenográfia határozza meg a kiállítás befogadását, hanem a befogadóhoz alkalmazkodik a kiállítási környezet, ami folyamatosan változik annak megfelelôen, hogy a befogadó mennyi idôt tölt egy-egy múalkotással. A befogadó fogja a különböző múveket magához vonzani, másokat pedig eltaszítani annak függvényében, hogy addig miket részesített elônyben, és melyikükkel töltött több idôt. Ebben a rendszerben a múvek folyamatos mozgásban vannak, ahogy a látogató aktivitására reagálnak.

A Les Immatériaux esetében nem a szcenográfia folyamatos újraalkotására helyezzük a hangsúly, hanem inkább a befogadó által bejárt útvonal lekövetésére, de az immerzió itt is nagyon fontos aspektus, amit föleg a kiállításhoz tartozó hanganyagon keresztül igyekszünk elérni.

Török Ervin: Nagyon izgalmas az immaterialitás kérdése, ami szerepel a francia kiállítás címében is. Tudjuk, hogy nagyon hosszú projektnek volt az eredménye a voltaképpeni kiállítás, a szervezés legalább nyolcvankettôben elkezdôdött, és nagyon sok munkacímen futott még azelôtt, hogy Lyotard-t felkérték volna az egyik fố kurátornak. Az egyik ilyen munkacím bizonyos értelemben ellentétes azzal, ami a kiállítás végsô címe lett: „La Matière dans tous ses états”, ,az anyag minden állapotában vagy rendjében", aztán ebból lett a Les Immatériaux, ami mintha pont az ellenkezójét mondaná: egyfajta anyagtalanságról beszél. Nyilván a technika akkori körülményei között az anyagtalanság mást jelentett, mint amit manapság jelent. Nagyon izgalmas dolog, hogy hogyan 
lehet lefordítani ezt a nagyon különös kontextust, amit Lyotard létrehozott az anyagiság kérdéseivel kapcsolatosan. Errốl nagyon sok minden olvasható és tényleg rettenetesen kíváncsi vagyok, hogy ezt hogyan értelmezitek, hogyan jön létre a fordításnak ez a munkája.

A másik dolog az immerzió kérdése, ami nyilván egyfajta hívószóvá vált a digitális technológiákkal kapcsolatosan. A Les Immatériaux kapcsán külön érdekes, hogy az egyik interjújában Lyotard a szomorúságra hivatkozik. Valahogy úgy fogalmaz, hogy a kiállításnak egy bizonyos fajta szomorúságot kell kiváltania. Egyrészrôl a technika és a technológia fölötti ujjongást, másrészrôl egyfajta szomorúságot. És ez bizonyos értelemben megint csak összefügg az anyagiságnak a furcsa hatásaival vagy tárgy nélküli hatásokkal, ami a látogatót éri, ahogy végigmegy ezen a nagyon különös téren fülhallgatóval a fején - ami akkor nyilván nagy technológiai újításnak számított. Az immerzivitás (mint a nézô bevonása) nyilván egyféle hatásmechanizmus, amit egy bizonyos médium kivált. A kurátorok egyik célja a különös tapogatózás lehetett a technológia lehetséges érzelmi hatásait illetôen, aminek csak egyik formája ez a fajta immerzív gyakorlat, a bevonás, a másik oldala pedig éppen egyfajta eltávolító hatás. Érzésem szerint az eltávolításra vagy korábbi hatásmechanizmusok elérhetetlenné válására is utalhatott. Mintha épp a distanciának az aspektusaival játszott volna a Les Immatériaux.

L. N-R.: A Beyond Matter projekt során az említett két kiállítást egységként kezelve értelmezzük. A Les Immatériaux esetében a materialitásnak különösen kiemelt jelentôsége van, az Iconoclash esetében pedig inkább a reprezentáció kérdésköre kerül elótérbe. Ugyanakkor mind a kettônek van egyrészt technológiai, másrészt pedig politikai vetülete, ami az Iconoclash esetében talán egy kicsit jobban tetten érhetô Bruno Latour több, az Iconoclasht követô kiállításában a ZKM-ben, amelyek kifejezetten politikai kérdésekkel foglalkoztak és foglalkoznak (Making Things Public: Atmospheres of Democrarcy, 2005; GLOBALE: Reset Modernity!, 2016; Critical Zones. Observatories for Earthly Politics, 2020).

A Les Immatériaux esetében ugyanakkor én azt gondolom, hogy a kiállítás címe nem feltétlenül a materialitás tagadását jelenti. Sốt; Lyotard írásaiból nem az derül ki, hogy ô a materialitás ellenzôje lenne. Ugyanakkor a kiállítás szcenográfiája egy bizonyos elemeltséget, immaterialitást próbál sugallni, például azzal, hogy nem épültek falak a kiállítótérben, hanem áttetszô fém hálókat függesztettek be, posztamensek helyett pedig függesztve mutattak be kiállítási tárgyakat, amelyek nem csak képzômúvészeti alkotások, hanem különféle anyagok voltak. Ezt a közvetlen anyagiságot a digitális modellben, részben az online hozzáférés korlátai miatt, nem lehet visszaadni, azaz a koncepció haptikus része csorbul. Viszont az immerzió, mint olyan, ugyanúgy adott lehet, mint a fizikai kiállítások esetében, legfeljebb kicsit más formában.

Említetted a szomorúságot és a distanciát; ezek kétségtelenül olyan fogalmak, melyek felmerülnek a Les Immatériaux koncepciójában, de én inkább egy másik aspektust emelnék ki a koncepcióból: Lyotard céljául tûzte ki a látogató elveszejtését a kiállítótérben, ami a posztmodernitás lyotard-i fogalmával tökéletesen összhangban van, mely szerint nem írható le egy fö narratíva, hanem különböző összefüggés nélküli mikrotörténet vesz minket körül. A kiállítás szcenográfiája, szintén 
ezzel összhangban, egy barlangszerú folyosóval indul, amelynek a végén egy kisebb térból (Théâtre du non-corps) induló négy lehetséges útvonal közül választhat a látogató, amelyek négy párhuzamos tematikus csapást is jelentenek. De ezt a feliratok vagy az audioguide nem teszik világossá. Inkább az a cél, hogy a kiállítás rendszere rejtve maradjon, és hogy a látogató bolyongjon a kiállításon belül.

Míg a valós térben a dezorientáció érzetét meghatározott eszközök segítségével lehet elérni, a digitális térben elveszejteni valakit alapeset, avagy borzasztó könnyú feladat, sokkal könnyebb, mint egy jól körülhatárolt narratívát és egy könnyen értelmezhetô teret létrehozni.

Sz-M. Z.: Én sem gondolom, hogy ezekben az online is megnézhetố történetekben éppen az anyagszerúség lenne a kulcsfogalom. A közfelfogás szerint a képzômúvész persze alapvetôen kézmúves munkát végez, egyedi és megismételhetetlen tárgyakat hoz létre, ám a gyakorlatban ez a tökéletességre törekvés leginkább abban nyilvánul meg, hogy minél gondosabban próbáljuk finomhangolni, azaz a kézmúves kezében tartani azt a látványt, tapasztalatot, amivel a befogadó találkozik. Ez egyébként a White Cube gondolatában, a minden zavaró tényezônek a múélvezetböl való kizárásában is megnyilvánult. Ahogy említetted, nem volt ez mindig így, a Giardini pálmaháza szép példája annak, ahogy eredetileg a kiállítóterek megpróbálták megidézni azt a helyzetet, ahogy az emberek otthonában a múvek jelen vannak, ahol a múvek otthonra lelnek. A White Cube sterilitása olyan múzeumi, illetve galériakörnyezetet teremtett, ahol a múvek otthontalanok; amint kikerülnek ebbôl az életidegen közegboól, számos zavaró tárgy, az élet nyomai veszik ôket körül - az elitizmus gondolata az én értelmezésemben leginkább azt jelenti, hogy onnantól megszúnnek befogadható múvek lenni, berendezési tárgyakká változnak.

De visszatérve a kézmúves gondosságra: a hálózati múvészet hajnalán, a kilencvenes években valószínúleg épp a White Cube diadalútjából adódóan - a múvészek számára talán azt volt a legnehezebb elfogadni, hogy csak nagyon korlátozottan van ráhatásunk arra, hogy mi és milyen összefüggésben kerül a befogadó elé. Nem csak azt nem tudjuk, milyen megjelenítőn, milyen más tartalmak társaságában találkozik a befogadó egy alkotással, de azt sem, hogy fotelban ülve vagy hason fekve, esetleg éppen virslit vacsorázva tekinti-e meg remekmúvünket.

A belemerülés vagy immerzivitás kapcsán azonban van egy elônye is ennek a helyzetnek: az otthonos környezet biztonságában sokkal könnyebb táncba vinni a nézốt, sokkal bátrabban mer kísérletezni, játszadozni azzal, ami elé kerül. Arra figyel, ami a monitorján látható, könnyedén kizárja a környezetét, a nem oda tartozó dolgokat. Szabadon választ abból, amit elérhetôvé teszünk számára, nem kell félni attól, hogy túl sokat tárunk elé, „túlterheljük”. Ha éppen nem ér rá, egy késóbbi idôpontban visszatér és megnézi azt, amire nem jutott ideje, türelme. Egy fizikai kiállítótér befogadóképessége számtalan olyan korlátot jelent a kiállításrendezô számára, mely megalkuvásokra kényszeríti.

Elveszik viszont a nézô számára a fizikai tér élménye és ezzel összefüggésben számos olyan információ, kapcsolat, mely a kiállított tárgyak méreteiból, dimenzióiból adódik. Online elérhetô mesterséges világokban képesek vagyunk bejárható számítógépes, virtuális tereket létrehozni, ám 
barangolás közben a nézô csak a kezét mozgatja egy néhány centiméteres területen. Miközben bejár hatalmas tereket, nincs tisztában azok dimenzióival, az arányokkal, igazából még az irányokkal, a megjelenített tárgyak egymáshoz képest elfoglalt térbeli helyzetével sem.

Említetted, hogy a hálózati változat mellett lesz egy kiállítótermi megjelenés is. Ez azt is jelenti, hogy a hálózati megjelenésre tervezett múveknek kell hogy legyen egy kiállítótermi változata is. Számomra leginkább az a kérdés, hogy hogyan lehet ezt a kettôsséget létrehozni, hogyan lehet a virtuális múvekhez olyan fizikai megjelenést rendelni, ami valami pluszt ad ehhez - és ez a plusz szerintem leginkább a tér lehet és nem az anyag.

L. N-R.: Pontosabban a tér élménye inkább, mivel nem tudjuk újra felépíteni ezt a két kiállítást. Pedig milyen izgalmas lenne a modellt az eredeti kiállítótér fölé helyezni egy digitális rétegként, ami aztán kiterjesztett valóságként megtekinthetô ugyanott, ahol a kiállítás volt - de ez csak egy zárójeles mellékgondolat. Az Immaterial Display azért tudja a tér élményét jobban átadni, mint egy online, asztali számítógépen nézett kiállításmodell, mert látogatójának egy adott pontról, pontosabban egy székból kell majd a kiállításmodellt megnéznie és bejárnia. Most éppen egy olyan kontroller van fejlesztés alatt, ami egybeépül a székkel, azaz a látogató a saját mozgásán keresztül is irányítja azt, hogy merre megy, mit csinál a digitális térben, ami pedig elôtte egy egészen a padlóig érô, a látóteret majdnem teljesen betöltő kivetítőn lesz látható.

Maguk a múvek, amelyek a kiállított modellváltozatban jelennek meg, lényegileg nem változnak, sok esetben azonban a digitális reprodukciók készítése nem feltétlenül célravezetô. Különösen igaz ez az olyan interaktív vagy több vetítést magukba foglaló installációk esetében, ahol már eleve nem egy White Cube-nak megfelelố atmoszféra megteremtése volt a múvészek célja, hanem saját rendszerüket próbálták meg a kiállítás szcenográfiáján belül kialakítani. Ezek sajátos esetek. Viszont szobrok, festmények, fotók, vitrinek esetében azok leegyszerúsített digitális modelljét fogjuk a kiállítás architektúrájával együtt mozgatni a térben. Ezen felül is tartozni fog a modellhez egy olyan réteg, amely a látogatók a kiállított múvek tartalmában való elmélyedését segíti, itt nagyobb felbontású reprodukciók, hanganyagok, videók és minden olyasmi látható és hallható lesz, ami egy viszonylag hú kép kialakításához szükséges - arról, hogy mi is az a mútárgy, amelynek a digitális csontvázával szembesülünk.

Sz-M. Z.: Említetted, hogy a munka kezdetén az eredeti elképzelések nagyon óvatosak voltak azzal kapcsolatban, hogy egy virtuális térben mit lehet, mit érdemes csinálni a néhai kiállítások megidézése kapcsán. Beszélnél egy picit arról, hogy mennyiben változtak, mennyiben gazdagodtak az eredeti elképzelések?

L. N-R.: Az, hogy bátrabbak lettünk, leginkább annak köszönhetô, hogy idôközben elkészült hét interjú az Iconoclash kurátoraival, a Centre Pompidou pedig tovább folytatta a Les Immatériaux-val kapcsolatos kutatásait. Utóbbi egy eleve nagyon jól kikutatott kiállítás, amelyrôl rengeteg publikáció jelent meg. A kutatásoknak, illetve a korabeli résztvevőkkel való beszélgetéseknek köszönhetôen bátrabbakká váltunk azzal kapcsolatban, hogy nem feltétlenül kell a kiállításokat egy az egyben digitalizálni. A digitális tér egy új platformot jelent, új médiumot. Ahogy Bruno Latour 
kitűnôen összefoglalta: az Iconoclash eddig két platformon jelent meg, az egyik a katalógus volt, a másik pedig a kiállítás, most pedig ez lesz a harmadik manifesztációja az ötletnek. Az egyes megjelenéseknél gyakorlatilag csak a keretrendszer változik, a téma ugyanaz marad.

Mindkét kiállítás kapcsán sok értelmezés született az azóta eltelt időben, a Les Immatériaux még jobban vonzotta az elmúlt két évtizedben a kutatókat, mint az Iconoclash. Mindenesetre ezek az értelmezések mindenképpen befolyásolják, hogy a digitális modell hogyan viszonyul az eredetihez, hiszen olyan jelentésekkel gazdagították az eredetit, melyektól mi, akik a kiállítással foglalkozunk, nem tudunk eltekinteni. Az 1985-ben és 2002-ben megvalósult kiállításoktól másmás távolságra vagyunk ma, 2021-ben, így az összes kurátortól, akit el tudtunk érni, megkérdeztem azt is, hogy mit változtatna az általa eredetileg elképzelt kiállításrészeken, és hogy mit ad hozzá tartalmilag az, hogy most egy ilyen digitális változat jön létre. Nagyon sokféle választ kaptam, Boris Groys például kiemelte a nosztalgia szerepét, Peter Gallisonnel pedig a mesterséges intelligencia képromboláshoz füződô viszonyáról beszélgettünk, ami ma mindenképpen része lenne az általa kurált kiállításrésznek: a közelmúltban egy fekete lyukról elkészült első „fotó” pedig az ô tudományos ikonoklazmust körüljáró kiállításrészének nyilván központi eleme lett volna. Messze vezet a lehetséges továbbfejlesztések és kiegészítések aspektusa.

T. E.: Nagyon fontos mindkét kiállítás esetében, hogy az európai gondolkodást meghatározó filozófusok léptek fel kurátorként. Bizonyos értelemben mindkét vállalkozás filozófiai projekt, így az eszméknek ez a fajta láthatóvá tétele, bemutatása a történetiségével együtt hozzá kell tartozzon az „újrafordításhoz”, ami nyilván nagyon nehézzé teszi a munkát.

L. N-R.: Nem feltétlenül nehézzé, hanem inkább érdekesebbé teszi. Két olyan filozófusról van szó, akiknek sajátos a viszonyuk a modernitáshoz. Lyotard sokak számára posztmodern filozófusként ismert, míg Latourt „nem modern” filozófusként szokták aposztrofálni. Ami abból a szempontból érdekes, hogy mi olyan technológiákkal foglalkozunk, amelyek a modernitás nélkül nem jöhettek volna létre, gyakorlatilag az elôfeltételük a modernitás. Ugyanakkor mindkét filozófiai rendszer esetében a modernitás megakadásáról, botladozásáról vagy akár bomlásáról van szó. Nem egyszerú ezt összehozni azzal, hogy mi egy bináris rendszeren keresztül próbálunk meg egy olyan alapvetôen nem bináris hozzáállást megvalósítani, amiben a jelenlét és a távollét egymástól nem elválasztható. Ennek egyik következménye az, hogy kénytelenek leszünk egy szótárt is írni a projekthez, mert nagyon sokszor azt érzem, hogy olyan jelenségekbe botlunk, amelyeket nem feltétlenül írtak még le ebben a kontextusban. Így ez a munka is részben ránk hárul.

Sz-M. Z.: Szerencsére lehet ez egy folyamatos fejlesztés tárgya is; sokat szoktunk arról beszélni, hogy a távjelenlét világában milyen sok dolog hiányzik nekünk a fizikaiból, és egyre kevesebbet annak elônyeirôl. Márpedig a fejleszthetôség, a folyamatos alakítás az online világ kétségtelen elônye, ahol nincsenek fizikai korlátok, sốt határidôn, vagy bemutatón, megnyitón túl is lehet tovább dolgozni valamin.

L. N-R.: Nem feltétlenül szerencsés, ha a digitális és a valós teret folyton szembeállítjuk egymással. 
Ahogy Bruno Latour fogalmaz, ezek más-más keretrendszerek. Ha elfogadjuk azt, hogy bizonyos dolgok az egyikben lehetségesek, amelyek a másikban nem, és viszont, akkor ennek megfelelôen alakítva a koncepció átadásának feltételeit a digitális és a valós tér ugyanúgy alkalmas lehet arra, hogy kiállításokat rendezzünk benne.

\section{Jegyzetek}

1. Center for Art and Media Karlsruhe. https://zkm.de/en

2. Walter Benjamin: Das Kunstwerk im Zeitalter seiner technischen Reproduzierbarkeit (1936). In Walter Benjamin: Gesammelte Schriften. I.2. kötet. Abhandlungen. Szerk. Rolf Tiedemann és Hermann Schweppenhäuser. Suhrkamp, Frankfurt am Main, 1980. 471-508. Magyarul a Médiatörténeti szöveggyüjteményben olvasható. Szerk. Peternák Miklós [Szegedy-Maszák Zoltán. Budapest. Intermédia, 2011. 86-97. URL: http://mek.niif.hu/19500/19557/19557.pdf

3. Tamkó Sirató Károly: Dimenzionista manifesztum. URL: https://artpool.hu/TamkoSirato/manifeszt.html

4. Nikolett Erôss: White Cube. In A kurátori gyakorlat és diszkurzus szótára. URL: http://tranzit.org/curatorialdictionary/index.php/dictionary/white-cube/ 
(C) Apertúra, 2021. tél | www.apertura.hu

webcím: https://www.apertura.hu/2021/tel/szegedy-maszak-az-anyagon-tul-livia-nolasco-

rozsassal-szegedy-maszak-zoltan-es-torok-ervin-beszelget/

https://doi.org/10.31176/apertura.2021.16.2.4

(Q) opertúro 